\title{
Does protocatechuic acid, a natural antioxidant, reduce renal ischemia reperfusion injury in rats?
}

\author{
Melih Yüksel, M.D., ${ }^{1}$ Murat Yıldar, M.D.,, ${ }^{2}$ Murat Başbuğ, M.D., ${ }^{2}$ Faruk Çavdar, M.D., ${ }^{2}$ \\ Öztekin Çıkman, M.D., ${ }^{3}$ Hasan Akşit, M.D., ${ }^{4}$ Figen Aslan, M.D., ${ }^{5}$ Dilek Akşit, M.D. ${ }^{6}$ \\ ${ }^{1}$ Department of Emergency Medicine, Balıkesir University Faculty of Medicine, Balıkesir-Turkey \\ ${ }^{2}$ Department of General Surgery, Balıkesir University Faculty of Medicine, Balıkesir-Turkey \\ ${ }^{3}$ Department of General Surgery, Çanakkale Onsekiz Mart University Faculty of Medicine, Çanakkale-Turkey \\ ${ }^{4}$ Department of Biochemistry, Balıkesir University Faculty of Veterinary, Balıkesir-Turkey \\ ${ }^{5}$ Department of Pathology, Balıkesir University Faculty of Medicine, Balıkesir-Turkey \\ ${ }^{6}$ Department of Pharmacology and Toxicology, Balıkesir University Faculty of Veterinary, Balıkesir-Turkey
}

\section{ABSTRACT}

BACKGROUND: Protocatechuic acid (PCA), which has antioxidant property, is a simple phenolic compound commonly found in many plants, vegetables, and fruits, notably in green tea and almonds. Present study was an investigation of the effects of PCA on rat kidney with ischemia/reperfusion (IR) injury.

METHODS: Sprague-Dawley rats were randomly divided into 4 groups: (I) Sham, (2) Renal IR, (3) Renal IR+Vehicle, and (4) Renal IR+PCA. Renal reperfusion injury was induced by clamping renal pedicle for 45 minutes after right nephrectomy was performed, followed by reperfusion for 3 hours. Dose of $80 \mathrm{mg} / \mathrm{kg}$ PCA was intraperitoneally administered to I group immediately before renal ischemia; $33 \%$ polyethylene glycol was used as vehicle. Total antioxidant status (TAS), malondialdehyde (MDA), superoxide dismutase (SOD), tumor necrosis factor alpha (TNF- $\alpha$ ), and interleukin- 6 levels were measured in blood and kidney tissue samples taken from sacrificed rats. Kidney tissue samples were examined and scored histopathologically. Terminal deoxynucleotidyltransferase-mediated dUTP digoxigenin nick end labeling assay method was used to detect apoptotic cells.

RESULTS: It was found that PCA significantly reduced serum MDA, TNF- $\alpha$, and kidney MDA levels, while it increased serum and kidney TAS and SOD levels. Histopathological scores were significantly higher for the group given PCA.

CONCLUSION: PCA reduced oxidative stress and can be used as an effective agent in treatment of renal IR injury.

Keywords: Antioxidants; ischemia reperfusion injury; malondialdehyde; protocatechuic acid; reactive oxygen species.

\section{INTRODUCTION}

One of the primary causes of acute kidney injury is ischemia/ reperfusion (IR) injury. ${ }^{[I]}$ IR can develop in circumstances such as hemorrhagic shock, renal transplantation, and urological surgical procedures that require temporary interruption of blood flow to the kidney, and may lead to loss of the organ. ${ }^{[1-3]}$

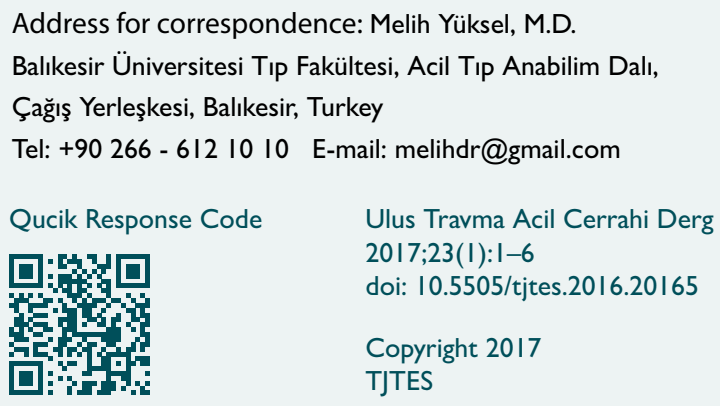

Reactive oxygen species (ROS) in the body, which ordinarily have low to moderate concentration, have roles in beneficial physiological functions, including cell signaling and defense against infection. ${ }^{[4]}$ However, in case of post-ischemic reperfusion, for example, protein, lipid, DNA, and mitochondrial damage occur in the cells due to excessive production of intracellular ROS. ${ }^{[1,4]}$ This damage is the beginning of the apoptosis process. As a result of renal tubular cell damage, renal function deteriorates. ${ }^{[2,5]}$

Antioxidant agents are known to decrease IR. ${ }^{[6]}$ Protocatechuic acid (PCA) is a benzoic acid derivative found in vegetables, nuts, brown rice, and fruit, as well as herbal medicines. ${ }^{[7,8]}$ The antioxidant effects of PCA have been demonstrated in previous studies. ${ }^{[9-11]}$ Anti-inflammatory, analgesic, antiplatelet, antiallergenic, antibacterial, antidiabetic, antineoplastic, antiapoptosis, and neuroprotective properties of PCA have been reported..$^{[7,9,12-21]}$ Additionally, it has been stated in various 
studies that PCA particularly reduces acute lung injury and cerebral ischemia, as well as IR injury in the liver and spleen. [22-25] This study was investigation of effects of PCA on renal IR injury, which has not been discussed in previous studies.

\section{MATERIALS AND METHODS}

\section{Animal Testing and Treatment Procedures}

Before the study was conducted, the approval of the Çanakkale 18 Mart University animal ethics committee was granted. Unlimited access to food and water was provided to all animals and they were treated humanely, according to the guidelines and the rules of the US National Institutes of Health regarding laboratory animal care and use of animals throughout the protocol.

Total of 24 male Sprague-Dawley rats weighing approximately 250 to $300 \mathrm{~g}$ each were randomly divided into 4 groups: (I) Sham ( $n=8)$, (2) Renal IR $(n=8)$, (3) Renal IR+Vehicle $(n=8)$, and (4) Renal IR+PCA $(n=8)$. Anesthesia was administered to experimental subjects via intramuscular ketamine/xylazine (Ketalar; Pfizer, Inc., NY, NY, USA/Rompun; Bayer AG, Leverkusen, Germany) $90 / 10 \mathrm{mg} / \mathrm{kg}$. Renal reperfusion injury was induced through reperfusion performed for 3 hours following right nephrectomy and clamping the left renal pedicle for 45 minutes. Next, $80 \mathrm{mg} / \mathrm{kg}$ dose of PCA ethyl ester (Sigma-Aldrich, Corp., St. Louis, MO, USA), which is used therapeutically, was administered intraperitoneally to PCA group immediately before development of renal ischemia. As PCA was solid, saline with $33 \%$ polyethylene glycol was used as vehicle. During laparotomy, $50 \mathrm{~mL} / \mathrm{kg}$ warm $0.9 \%$ sodium chloride was added to the abdominal cavity, and 3 hours after laparotomy closure, all rats were sacrificed. Total antioxidant status (TAS), malondialdehyde (MDA), superoxide dismutase (SOD), tumor necrosis factor alpha (TNF- $\alpha$ ), and interleukin-6 (IL-6) levels in blood samples and kidneys were analyzed. Kidney tissue samples were used for histopathological scoring. Terminal deoxynucleotidyltransferase-mediated dUTP digoxigenin nick end labeling (TUNEL) assay was used to detect apoptotic cells.

\section{Antioxidant Enzymes, Pro-Inflammatory Cytokines, and MDA Measurement}

Blood samples taken from rats were incubated for 2 hours at room temperature to allow for clotting. Samples were centrifuged at $2500 \mathrm{~g}$ for 15 minutes at $4^{\circ} \mathrm{C}$ and then kept at $-20^{\circ} \mathrm{C}$. Lipid peroxidation was examined via procedure demonstrated by Yoshioka. ${ }^{[26]}$ During the procedure, MDA, which is the final product of peroxidation of fatty acids, reacts with TBA at $532 \mathrm{~nm}$ to form a colored compound with maximum absorbance. The method developed by Rel to measure antioxidative influence of the sample against the potent reactive radical reactions started by the reduced hydroxyl radical was utilized to evaluate TAS of the serum. Data were expressed as mmol Trolox equiv/L. In order to assess SOD activity in se- rum, it was incubated with xantine oxidase solution for I hour at $37^{\circ} \mathrm{C}$. Absorbance was measured at $490 \mathrm{~nm}$ to allow for creation of superoxide anions. Activity of SOD was considered inhibition of chromagen decrease. Superoxide anion concentration decreases in presence of SOD, which leads to less colorimetric signal. SOD activity was expressed as percentage. To assess serum concentration of TNF- $\alpha$ and IL-6, double sandwich enzyme-linked immunosorbent assay kits (Thermo Fisher Scientific, Inc., Waltham, MA, USA) were used. ELISA plates were evaluated using microplate reader at $450 \mathrm{~nm}$.

\section{Histopathological Examination}

For histopathological examination, tissue samples from 4 groups were identified using $10 \%$ formalin and routine procedures were performed. Sections $5-\mu \mathrm{m}$ thick were taken from paraffin-embedded tissue and stained with hematoxylin eosin. Light microscope was used to examine hydropic degeneration, tubular dilation, pyknotic nucleus, cell caste in tubulin (debris), and congestion in kidney tissue. Each parameter was scored semi-quantitatively from 0 to 3 , i.e., no pathology: 0 points, focal: I point, multifocal: 2 points, and diffuse: 3 points.

\section{TUNEL Staining to Detect Apoptotic Cells}

Apoptotic cells in kidneys were identified by doctor who was blinded to group assignments using TUNEL assay. TUNEL assay kit was used according to the manufacturer's instructions (ApopTag Peroxidase In Situ Apoptosis Detection Kit, S7I0IKIT; Merck Millipore, Corp., Billerica, MA, USA).

\section{Statistical Analysis}

Results were expressed as mean $\pm S D$. Data were analyzed using SPSS 20.0 (IBM, Corp., Armonk, NY, USA) software. Analysis of variance was used to compare all groups. In addition, Tukey's range test was used as post hoc analysis. $P$ value of 0.05 or less was considered statistically significant.

\section{RESULTS}

\section{Effects of PCA on TAS, SOD, and MDA Level}

Serum TAS and SOD values, measured at $2.67 \pm 0.23$ and $64.51 \pm 9.62$, respectively, in the Sham group, were significantly lower in the Renal IR group (TAS: $1.78 \pm 0.23$, SOD: 48.15 $\pm 4.03 ; p<0.001, p<0.001$ ). These values were elevated in Renal IR group compared with groups given vehicle before renal IR; however, this change was not statistically significant (TAS: I.88 \pm 0.27 , SOD: $49.17 \pm 2.11$; $p=0.856, p=0.989$ ). Values were significantly greater in group given PCA compared with Renal IR group (TAS: $2.36 \pm 0.12$, SOD: $57.37 \pm 3.53$; $p=0.00$ I, $p=0.45$ ). Serum MDA value, with mean score of $10.82 \pm 0.75$ in the Sham group, was significantly greater in Renal IR group $(17.00 \pm 2.93 ; p<0.00 I)$. That value was lower in groups given vehicle before renal IR, but decrease was not significant $(15.96 \pm 1.96 ; p=0.760)$. In group given PCA prior to renal IR, it was found that value was significantly lower compared with Renal IR group (II.65 $\pm 0.68 ; \mathrm{p}<0.00 \mathrm{I})$ (Table I, Figure I). 
Table I. The mean serum TAS, MDA, SOD, TNF- $\alpha$, and IL-6 level in all experimental groups

\begin{tabular}{|c|c|c|c|c|c|}
\hline \multirow[t]{2}{*}{ Groups } & \multirow{2}{*}{$\frac{\text { TAS (mmol trolox Equiv./L) }}{\text { Mean } \pm S D}$} & \multirow{2}{*}{$\frac{\text { MDA }(\mu \mathrm{mol} / \mathrm{L})}{\text { Mean } \pm S D}$} & \multirow{2}{*}{$\frac{\text { SOD (\% inhibition) }}{\text { Mean } \pm \text { SD }}$} & \multirow{2}{*}{$\frac{\text { TNF- } \alpha(\mathrm{pg} / \mathrm{mL})}{\text { Mean } \pm \text { SD }}$} & \multirow{2}{*}{$\frac{\text { IL-6 }(\mathrm{pg} / \mathrm{mL})}{\text { Mean } \pm \text { SD }}$} \\
\hline & & & & & \\
\hline Sham & $2.67 \pm 0.23$ & $10.82 \pm 0.75$ & $64.51 \pm 9.62$ & $79.55 \pm 7.63$ & $22.92 \pm 5.64$ \\
\hline Renal IR & $1.78 \pm 0.23^{*}$ & $17.00 \pm 2.93^{*}$ & $48.15 \pm 4.03^{*}$ & $104.02 \pm 8.98^{*}$ & $34.34 \pm 2.47^{*}$ \\
\hline Vehicle & $1.88 \pm 0.27^{*}$ & $15.96 \pm 1.96^{*}$ & $49.17 \pm 2.1 I^{*}$ & $101.82 \pm 10.69^{*}$ & $35.79 \pm 2.68^{*}$ \\
\hline PCA & $2.36 \pm 0.12^{\dagger}$ & $11.65 \pm 0.68^{\dagger}$ & $57.37 \pm 3.53^{\dagger}$ & $85.97 \pm 5.02^{\dagger}$ & $30.43 \pm 2.7 I^{*}$ \\
\hline
\end{tabular}

"Compared with Sham group; $\mathrm{p}<0.05$. ${ }^{\dagger}$ Compared with Renal IR Group; $\mathrm{p}<0.05$.

IL-6: Interleukin-6; IR: Ischemia/reperfusion; MDA: Malondialdehyde; PCA: Protocatechuic acid; SOD: Superoxide dismutase; TAS: Total antioxidant status; TNF- $\alpha$ :

Tumor necrosis factor alpha.

Kidney TAS and SOD values, measured at $1.30 \pm 0.12$, and $58.06 \pm 4.70$, respectively, in Sham group, were significantly lower in Renal IR group (TAS: $0.86 \pm 0.14$, SOD: $38.14 \pm 4$.I3; $\mathrm{P}<0.00 \mathrm{I}, \mathrm{P}<0.00 \mathrm{I})$. These values were greater in the group given PCA prior to renal IR; however, change was not significant (TAS: $0.91 \pm 0.18$, SOD: $39.92 \pm 4.90 ; p=0.882, p=0$. 878). Values were significantly greater in group given $P C A$ compared with Renal IR group (TAS: I.I0 \pm 0.12 , SOD: 47.91 $\pm 2.27 ; p=0.014, p=0.003)$. Kidney MDA value, with mean of $13.09 \pm 1.1$ I for Sham group, was significantly greater in Renal IR group (19.24 $\pm 2.38 ; p<0.001)$. There was no significant difference seen in groups given vehicle before renal IR (I8.23 $\pm 2.31 ; p=0.793)$. Values were observed to be signifi- cantly lower in the group given PCA compared with Renal IR group ( $14.50 \pm 1.42 ; p=0.002$ ) (Table 2, Figure I).

\section{Effects of PCA on TNF- $a$ and IL- 6 Levels}

Serum TNF- $\alpha$ and IL- 6 levels, with mean measurement of $79.55 \pm 7.63$ and 22.92 \pm 5.64 , respectively, in Sham group, were significantly greater in Renal IR group (TNF- $\alpha$ : 104.02 \pm 8.98 , IL-6: $34.34 \pm 2.47 ; p<0.00 I, p<0.00 I)$. These values were greater in groups given vehicle prior to renal IR compared with Renal IR group. However, the increase in these markers was not significant (TNF- $\alpha$ : I0I.82 \pm 10.69 , IL-6: 35.79 \pm 2.68 ; $p=0.968, p=0.898)$. In addition, in group given PCA before renal IR, TNF- $\alpha$ levels were found to be significantly lower. IL-6
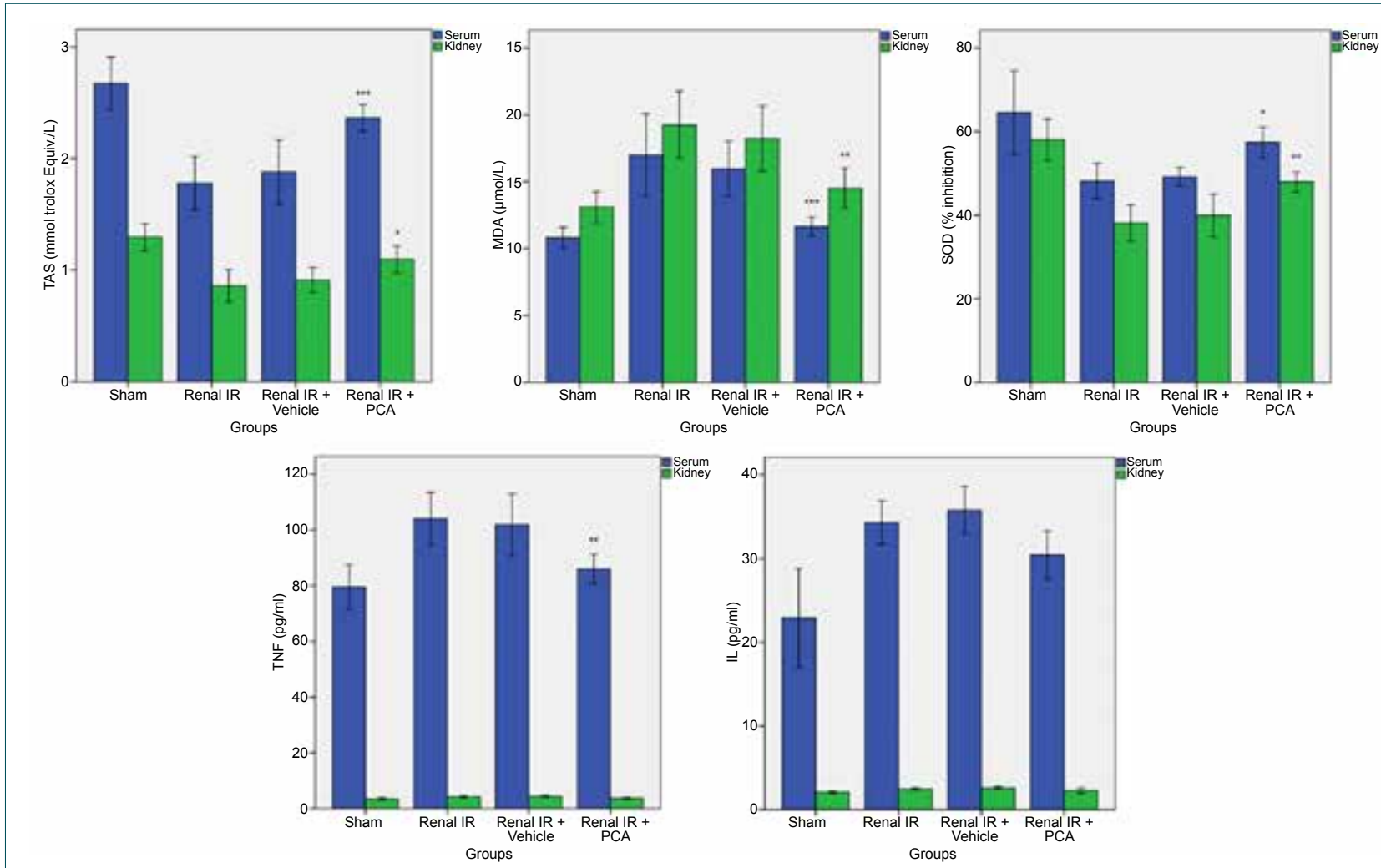

Figure 1. The mean TAS, MDA, SOD, TNF- $\alpha$, and IL-6 level in all experimental groups. IL-6: Interleukin-6; MDA: Malondialdehyde; SOD: Superoxide dismutase; TAS: Total antioxidant status; TNF- $\alpha$ : Tumor necrosis factor alpha. 
Table 2. The mean kidney TAS, MDA, SOD, TNF- $\alpha$ and IL-6 level in all experimental groups

\begin{tabular}{|c|c|c|c|c|c|}
\hline \multirow[t]{2}{*}{ Groups } & \multirow{2}{*}{$\frac{\text { TAS (mmol trolox Equiv./L) }}{\text { Mean } \pm S D}$} & \multirow{2}{*}{$\frac{\text { MDA }(\mu \mathrm{mol} / \mathrm{L})}{\text { Mean } \pm S D}$} & \multirow{2}{*}{$\frac{\text { SOD (\% inhibition) }}{\text { Mean } \pm \text { SD }}$} & \multirow{2}{*}{$\frac{\text { TNF- } \alpha(\mathrm{pg} / \mathrm{mL})}{\text { Mean } \pm \text { SD }}$} & \multirow{2}{*}{$\frac{\text { IL-6 }(\mathrm{pg} / \mathrm{mL})}{\text { Mean } \pm \text { SD }}$} \\
\hline & & & & & \\
\hline Sham & $1.30 \pm 0.12$ & $|3.09 \pm 1.1|$ & $58.06 \pm 4.70$ & $3.55 \pm 0.46$ & $2.10 \pm 0.18$ \\
\hline Renal IR & $0.86 \pm 0.14^{*}$ & $19.24 \pm 2.38^{*}$ & $38.14 \pm 4.13^{*}$ & $4.36 \pm 0.43^{*}$ & $2.50 \pm 0.14^{*}$ \\
\hline Vehicle & $0.91 \pm 0.18^{*}$ & $|8.23 \pm 2.3|^{*}$ & $39.92 \pm 4.90^{*}$ & $4.56 \pm 0.38^{*}$ & $2.61 \pm 0.16^{*}$ \\
\hline PCA & $1.10 \pm 0.12^{\dagger}$ & $14.50 \pm 1.42^{\dagger}$ & $47.91 \pm 2.27^{*}$ & $3.78 \pm 0.26$ & $2.29 \pm 0.31$ \\
\hline
\end{tabular}

${ }^{*}$ Compared with Sham group; $\mathrm{p}<0.05$. ${ }^{\dagger}$ Compared with Renal IR Group; $\mathrm{p}<0.05$.

IL-6: Interleukin-6; MDA: IR: Ischemia/reperfusion; Malondialdehyde; PCA: Protocatechuic acid; SOD: Superoxide dismutase; TAS: Total antioxidant status; TNF- $\alpha$ :

Tumor necrosis factor alpha.

levels were also found to be lower, but the decrease was not significant (TNF- $\alpha$ : 85.97 \pm 5.02 , IL-6: $30.43 \pm 2.7 \mathrm{I} ; \mathrm{p}=0.006$, $\mathrm{p}=0.27 \mathrm{I})($ Table I, Figure I).

Kidney TNF- $\alpha$ and IL- 6 levels, having mean score of $3.55 \pm 0.46$ and 2.10 \pm 0.18 , respectively, in Sham group, were significantly elevated in Renal IR group (TNF- $\alpha$ : $4.36 \pm 0.43$, IL-6: $2.50 \pm 0.14 ; p=0.010, p=0.01 \mathrm{I})$. Values had increased in groups given vehicle prior to renal IR compared with Renal IR group; however, increase in these markers was not significant
(TNF- $\alpha: 4.56 \pm 0.38, I L-6: 2.6 I \pm 0.16 ; p=0.794, p=0.750)$. In group given PCA before renal IR, TNF- $\alpha$ and IL- 6 levels were lower, but decrease was not significant (TNF- $\alpha$ : 3.78 \pm 0.26 , IL-6: 2.29 $\pm 0.3 \mathrm{I} ; \mathrm{p}=0.080, p=0.3 \mathrm{II}$ ) (Table, Figure I).

\section{Effects of PCA on Kidney Tissue}

During examination with light microscope of tissue sections stained with hematoxylin-eosin, hydropic degeneration in tubule epithelium, tubular dilation, pyknotic nucleus, cell caste
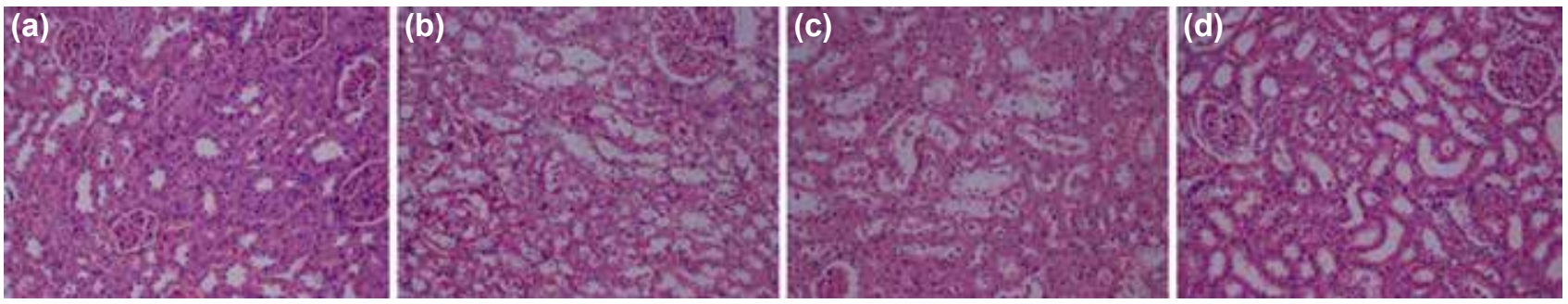

Figure 2. Hematoxylin and eosin (H\&E) stain of kidney tissue. (a) Sham group sample with normal kidney tissue structure (H\&E; x200); (b) Renal ischemia/reperfusion (IR) group sample with apparent tubular hidropic degeneration, intra-tubulin caste (debris) accumulation, pyknotic nuclei, and signs of congestion (H\&E; $\times 200)$; (c) Renal IR+Vehicle group sample with similar histopathological findings to renal IR group (H\&E; x200); (d) Significant decline in renal histopathological findings observed in IR+PCA group, and renal IR+Vehicle group. (H\&E; x200).
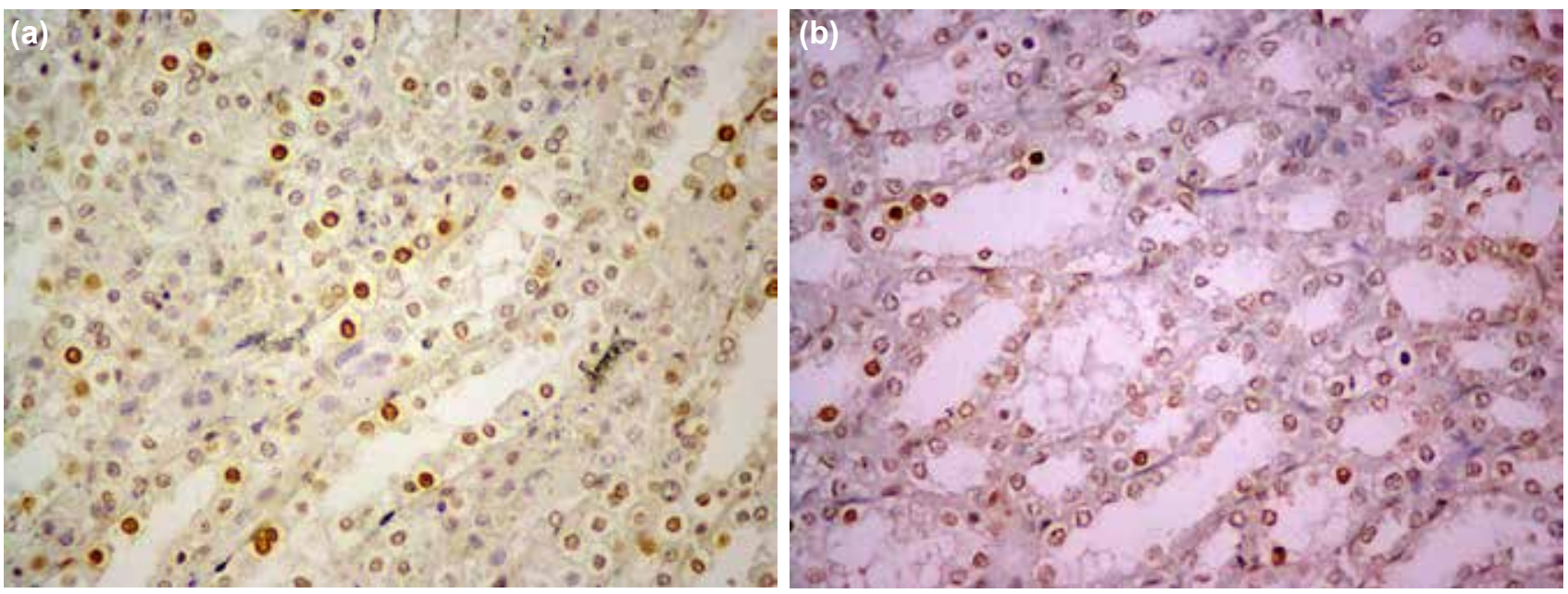

Figure 3. Terminal deoxynucleotidyltransferase-mediated dUTP digoxigenin nick end labeling (TUNEL) analysis for apoptotic cells shown (TUNEL; $x 400$ ). Nuclei of TUNEL-positive cells are stained brown, in contrast to blue-stained TUNEL-negative cells. (a) Renal ischemia/ reperfusion (IR) group; (b) Renal IR+PCA group. 
in tubulin (debris), and tissue damage symptoms, such as congestion, were clearly observed in IR group. Severity of tissue damage did not change in Renal IR+Vehicle group, while in Renal IR+PCA group, tissue damage was found to be less severe than in IR group (Figure 2). Mean score of tissue damage parameters was $1.85 \pm 1.22$ in Sham group, $10 \pm 0.82$ in IR group,

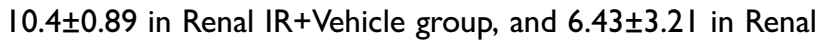
IR+PCA group. Mean score of tissue damage parameters was significantly lower in Renal IR+PCA group compared with IR group $(p<0.001)$.

\section{Effects of PCA on TUNEL Staining}

Substantial nuclear changes, including death of apoptotic cells as indicated by TUNEL-positive cells, were observed in the kidneys of IR group. PCA-treatment reduced the number of TUNEL-positive cells (Figure 3).

\section{DISCUSSION}

In this study, PCA was demonstrated to have protective influence on renal IR damage. Renal IR damage is known to be associated with cell apoptosis, caused by increased ROS and oxidative stress. ${ }^{[3]}$ Thus, treatment methods reducing ROS may also reduce oxidative stress, apoptosis, and renal IR damage. ${ }^{[3]}$ Antioxidative properties of PCA may be able to target different stages of the pathophysiological events that cause IR damage. As an antioxidant agent, the most likely way is to reduce ROS. ${ }^{[14]}$

Excessive production of ROS causes lipid peroxidation. MDA levels increase due to lipid peroxidation. ${ }^{[14,27]}$ It was found in the present study that MDA levels elevated in Renal IR group were lower in group with PCA treatment.

Endogenous antioxidants, such as SOD, protect cells from ROS damage. With increase in ROS production, SOD levels decrease. ${ }^{[4,23]}$ Decrease in SOD lowers antioxidant status. ${ }^{[28]}$ It was observed in this study that antioxidant components SOD and TAS, which decrease following renal IR, increased with PCA therapy.

It has been demonstrated that ROS, produced in tissues after $I R$, induces release of proinflammatory cytokines by stimulating macrophage. ${ }^{[29]}$ Proinflammatory cytokines, such as TNF- $\alpha$ and IL-6, cause polymorphonuclear leukocyte activation and play an important role in both tissue and distant organ damage. ${ }^{[29,30]}$ In our study, TNF- $\alpha$ and IL-6 levels were found to be lower with PCA treatment.

There are many studies showing that as result of renal IR, apoptosis and damage occur, particularly to the outer tubules of renal medulla. ${ }^{[2]}$ In our study, histopathological scoring performed with samples taken from the outer renal medulla was better in those subjects with PCA treatment, and apoptosis was decreased.

There are some limitations to our study. Primarily, we have not investigated dose and time dependent effects of PCA. Because effect of PCA on renal IR has not been previously documented, we investigated effects on constant reperfusion time and dose of PCA. We used 45 minute-ischemia and 3-hour reperfusion in this study. Unfortunately, for technical reasons, we could not measure glomerular filtration rate or tubular function, which might have supported our results indicating reduced renal IR damage.

The results of this study have demonstrated that PCA has a protective effect on renal IR injury by reducing oxidative stress and tissue damage. These effects of treatment with PCA, a natural antioxidant, on renal IR injury have been established for the first time with this study. PCA may be an effective agent to prevent renal IR if our results are supported by other experimental and clinical studies.

\section{Ethical Approval}

All applicable international, national, and/or institutional guidelines for the care and use of animals were followed. All experimental protocols conducted on the animals were consistent with the National Institutes of Health Guidelines for the Care and Use of Laboratory Animals and approved by the Çanakkale I8 Mart University ethical committee.

Conflict of interest: None declared.

\section{REFERENCES}

1. Yamamoto S, Hagiwara S, Hidaka S, Shingu C, Goto K, Kashima K, et al. The antioxidant EPC-K1 attenuates renal ischemia-reperfusion injury in a rat model. Am J Nephrol 2011;33:485-90. Crossre

2. Thadhani R, Pascual M, Bonventre JV. Acute renal failure. N Engl J Med 1996;334:1448-60. Crossret

3. Yildar M, Aksit H, Korkut O, Ozyigit MO, Sunay B, Seyrek K. Protective effect of 2-aminoethyl diphenylborinate on acute ischemia-reperfusion injury in the rat kidney. J Surg Res 2014;187:683-9. Crossre.

4. Valko M, Leibfritz D, Moncol J, Cronin MT, Mazur M, Telser J. Free radicals and antioxidants in normal physiological functions and human disease. Int J Biochem Cell Biol 2007;39:44-84. Crossret

5. Lee HT, Park SW, Kim M, Ham A, Anderson LJ, Brown KM, et al. Interleukin-11 protects against renal ischemia and reperfusion injury. Am J Physiol Renal Physiol 2012;303:F1216-24. Crossret

6. Nicoud IB, Knox CD, Jones CM, Anderson CD, Pierce JM, Belous AE, et al. 2-APB protects against liver ischemia-reperfusion injury by reducing cellular and mitochondrial calcium uptake. Am J Physiol Gastrointest Liver Physiol 2007;293:G623-30. Crossret

7. Wei M, Chu X, Guan M, Yang X, Xie X, Liu F, Chen C, Deng X. Protocatechuic acid suppresses ovalbumin-induced airway inflammation in a mouse allergic asthma model. Int Immunopharmacol 2013;15:780-8.

8. Chan K, Chui SH, Wong DY, Ha WY, Chan CL, Wong RN. Protective effects of Danshensu from the aqueous extract of Salvia miltiorrhiza (Danshen) against homocysteine-induced endothelial dysfunction. Life Sci 2004;75:3157-71. Crossre

9. Guan S, Ge D, Liu TQ, Ma XH, Cui ZF. Protocatechuic acid promotes cell proliferation and reduces basal apoptosis in cultured neural stem cells. Toxicol In Vitro 2009;23:201-8. Crossrel

10. Shi GF, An LJ, Jiang B, Guan S, Bao YM. Alpinia protocatechuic acid protects against oxidative damage in vitro and reduces oxidative stress in 
vivo. Neurosci Lett 2006;403:206-10. Crossret

11. Liu YM, Jiang B, Bao YM, An LJ. Protocatechuic acid inhibits apoptosis by mitochondrial dysfunction in rotenone-induced PC12 cells. Toxicol In Vitro 2008;22:430-7. Crossre

12. Lende AB, Kshirsagar AD, Deshpande AD, Muley MM, Patil RR, Bafna PA, et al. Anti-inflammatory and analgesic activity of protocatechuic acid in rats and mice. Inflammopharmacology 2011;19:255-63.

13. Lin CY, Huang CS, Huang CY, Yin MC. Anticoagulatory, antiinflammatory, and antioxidative effects of protocatechuic acid in diabetic mice. J Agric Food Chem 2009;57:6661-7. Crossre]

14. Muley MM, Thakare VN, Patil RR, Kshirsagar AD, Naik SR. Silymarin improves the behavioural, biochemical and histoarchitecture alterations in focal ischemic rats: a comparative evaluation with piracetam and protocatachuic acid. Pharmacol Biochem Behav 2012;102:286-93. Crossre]

15. Cao YG, Zhang L, Ma C, Chang BB, Chen YC, Tang YQ, et al. Metabolism of protocatechuic acid influences fatty acid oxidation in rat heart: new anti-angina mechanism implication. Biochem Pharmacol 2009;77:1096-104. Crossret

16. Deng JS, Lee SD, Kuo WW, Fan MJ, Lin YM, Hu WS, et al. Antiapoptotic and pro-survival effect of protocatechuic acid on hypertensive hearts. Chem Biol Interact 2014;209:77-84.

17. Song Y, Cui T, Xie N, Zhang X, Qian Z, Liu J. Protocatechuic acid improves cognitive deficits and attenuates amyloid deposits, inflammatory response in aged A $\beta P P / P S 1$ double transgenic mice. Int Immunopharmacol 2014;20:276-81. Crossret

18. Zhang HN, An CN, Xu M, Guo DA, Li M, Pu XP. Protocatechuic acid inhibits rat pheochromocytoma cell damage induced by a dopaminergic neurotoxin. Biol Pharm Bull 2009;32:1866-9. Crossree

19. Chao CY, Yin MC. Antibacterial effects of roselle calyx extracts and protocatechuic acid in ground beef and apple juice. Foodborne Pathog Dis 2009;6:201-6. Crossre

20. Scazzocchio B, Varì R, Filesi C, D'Archivio M, Santangelo C, Giovannini $\mathrm{C}$, et al. Cyanidin-3-O- $\beta$-glucoside and protocatechuic acid exert insulinlike effects by upregulating PPAR $\gamma$ activity in human omental adipocytes.
Diabetes 2011;60:2234-44. Crossret

21. Kim K, Bae ON, Lim KM, Noh JY, Kang S, Chung KY, et al. Novel antiplatelet activity of protocatechuic acid through the inhibition of high shear stress-induced platelet aggregation. J Pharmacol Exp Ther 2012;343:704-11. Crossre

22. Wang GZ, Yao JH, Jing HR, Zhang F, Lin MS, Shi L, et al. Suppression of the p66shc adapter protein by protocatechuic acid prevents the development of lung injury induced by intestinal ischemia reperfusion in mice. J Trauma Acute Care Surg 2012;73:1130-7. Crossre

23. Zhang X, Shi GF, Liu XZ, An LJ, Guan S. Anti-ageing effects of protocatechuic acid from Alpinia on spleen and liver antioxidative system of senescent mice. Cell Biochem Funct 2011;29:342-7. Crossret

24. Liu S, Liu M, Peterson S, Miyake M, Vallyathan V, Liu KJ. Hydroxyl radical formation is greater in striatal core than in penumbra in a rat model of ischemic stroke. J Neurosci Res 2003;71:882-8. Crossre]

25. Ma L, Wang G, Chen Z, Li Z, Yao J, Zhao H, et al. Modulating the p66shc signaling pathway with protocatechuic acid protects the intestine from ischemia-reperfusion injury and alleviates secondary liver damage. ScientificWorldJournal 2014;2014:387640. Crossret

26. Yoshioka T, Kawada K, Shimada T, Mori M. Lipid peroxidation in maternal and cord blood and protective mechanism against activated-oxygen toxicity in the blood. Am J Obstet Gynecol 1979;135:372-6. Crossre]

27. Ross D. Glutathione, free radicals and chemotherapeutic agents. Mechanisms of free-radical induced toxicity and glutathione-dependent protection. Pharmacol Ther 1988;37:231-49. Crossret

28. Al-Rubaei ZM, Mohammad TU, Ali LK. Effects of local curcumin on oxidative stress and total antioxidant capacity in vivo study. Pak J Biol Sci 2014;17:1237-41. Crossre.

29. Li L, Okusa MD. Macrophages, dendritic cells, and kidney ischemiareperfusion injury. Semin Nephrol 2010;30:268-77. Crossret

30. Rezende-Neto JB, Moore EE, Melo de Andrade MV, Teixeira MM, Lisboa FA, Arantes RM, et al. Systemic inflammatory response secondary to abdominal compartment syndrome: stage for multiple organ failure. J Trauma 2002;53:1121-8. Crossre]

\title{
DENEYSEL ÇALIŞMA - ÖZET
}

\section{Doğal bir antioksidan olan protokateşuik asit sıçanlarda renal iskemi reperfüzyon hasarını azaltıyor mu?}

\section{Dr. Melih Yüksel, ${ }^{1}$ Dr. Murat Yıldar, ${ }^{2}$ Dr. Murat Başbuğ, ${ }^{2}$ Dr. Faruk Çavdar, ${ }^{2}$ Dr. Öztekin Çıkman, ${ }^{3}$ Dr. Hasan Akşit, ${ }^{4}$ Dr. Figen Aslan, ${ }^{5}$ Dr. Dilek Akşit ${ }^{6}$}

\author{
${ }^{1}$ Balıkesir Üniversitesi Tıp Fakültesi, Acil Tıp Anabilim Dalı, Balıkesir \\ ${ }^{2}$ Balıkesir Üniversitesi Tıp Fakültesi, Genel Cerrahi Anabilim Dalı, Balıkesir \\ ${ }^{3}$ Çanakkale Onsekiz Mart Üniveristesi, Genel Cerrahi Anabilim Dalı, Çanakkale \\ ${ }^{4}$ Balıkesir Üniversitesi Veteriner Fakültesi, Biyokimya Anabilim Dalı, Balıkesir \\ ${ }^{5}$ Balıkesir Üniversitesi Tıp Fakültesi, Patoloji Anabilim Dalı, Balıkesir \\ ${ }^{6}$ Balıkesir Üniversitesi Veteriner Fakültesi, Farmakoloji ve Toksikoloji Anabilim Dalı, Balıkesir
}

AMAÇ: Protokateşuik asit (PCA) yeşil çay, fındık, badem başta olmak üzere birçok bitki, sebze ve meyvede yaygın olarak bulunan anti-oksidan özelliği olan basit bir fenol bileşiğidir. Bu çalışmada PCA'nın iskemi/reperfüzyon (IR) hasarı oluşturulan böbrekler üzerine olan etkilerini araştırmayı amaçladık. GEREÇ VE YÖNTEM: Sprague-Dawley cinsi sıçanlar rastgele dört gruba ayrıldı: (I) Sham, (2) Renal IR (3) Renal IR + Vehicle (4) Renal IR + PCA. Renal IR hasarı sağ nefrektomi yapıldıktan sonra 45 dakika boyunca sol renal pedikül klemplenip sonrasında üç saat boyunca reperfüzyon yapılarak indüklendi. Tedavi edici olarak kullanılan PCA renal iskemiden hemen önce $80 \mathrm{mg} / \mathrm{kg}$ dozunda intraperitoneal olarak uygulandı. Protokateşuik asiti çözmek için araç olarak \%33'lük polietilen glikol kullanıldı. Sıçanlar sakrifiye edildikten sonra alınan kan örmeklerinde ve böbrek dokusunda total antioksidan kapasite (TAS), malondialdehit (MDA), süperoksitdismutaz (SOD), tümör nekroz faktör alfa (TNF- $\alpha$ ), interlökin-6 (IL-6) seviyesi ölçüldü. Böbrek doku örneklerinde histopatolojik incelemeler yapılarak histopatolojik skorlama elde edildi. Apoptotik hücreleri görüntülemek için terminal deoxynucleotidyltransferase-mediated dUTP digoxigenin nick-end-labeling (TUNEL) boyama yapıldı.

BULGULAR: Protokateşuik asitin serum MDA ve TNF- $\alpha$ ile böbrek MDA seviyelerini anlamlı olarak azalttığı, serum ve böbrek TAS ile SOD seviyelerini ise anlamlı olarak artırdığı görüldü. Histopatolojik skorlamanın PCA verilen grupta anlamlı olarak daha iyi idi.

TARTIŞMA: Oksidatif stresi ve renal iskemi reperfüzyon hasarını azalttı̆̆ııı ortaya koyduğumuz PCA, IR hasarına karşı etkili bir ajan olarak kullanılabilir. Anahtar sözcükler: Antioksidanlar; iskemi reperfüzyon hasarı; malondialdehit; protokateşuik asit; serbest oksijen radikalleri.

Ulus Travma Acil Cerrahi Derg 2017;23(I):1-6 doi: 10.5505/tjtes.2016.20165 